\title{
C-Type Natriuretic Peptide/Natriuretic Peptide Receptor B Regulate the Expression and Secretion of Antibacterial Peptide S100A7 in Goat Mammary Gland Through PKG/JNK/c-Jun Signaling Pathway
}

\section{Mingzhen Fan}

Northwest A\&F University: Northwest Agriculture and Forestry University

Yutong Yan

Northwest A\&F University: Northwest Agriculture and Forestry University

Yuyang Miao

Northwest A\&F University: Northwest Agriculture and Forestry University

Kunyuan Zhu

Northwest A\&F University: Northwest Agriculture and Forestry University

Xiaoe Zhao

Northwest A\&F University: Northwest Agriculture and Forestry University

Menghao Pan

Northwest A\&F University: Northwest Agriculture and Forestry University

\section{Baohua Ma}

Northwest A\&F University: Northwest Agriculture and Forestry University

Qiang Wei ( $\square$ weiq@nwsuaf.edu.cn )

Northwest A \& F University https://orcid.org/0000-0003-0535-8506

\section{Research}

Keywords: C-type natriuretic peptide, natriuretic peptide receptor B, antibacterial peptide, S100A7, Mammary gland, Mastitis, Goat

Posted Date: November 16th, 2021

DOI: https://doi.org/10.21203/rs.3.rs-1066706/v1

License: (9) (1) This work is licensed under a Creative Commons Attribution 4.0 International License. Read Full License 


\section{Abstract \\ Background}

C- type natriuretic peptide (CNP) and its receptor natriuretic peptide receptor B (NPR-B) were members of natriuretic peptides system which were well known produced in cardiovascular and central nervous system. However, whether CNP/NPR-B is expressed in mammary gland, and what its role in mammary gland has not been reported. The antimicrobial peptide S100A7 is a critical component of the animal innate immune system and plays important roles to resist infection of pathogens in the mastitis. It is a hypothesis that CNP/NPR-B signaling pathway maybe induces the expression and secretion of S100A7 in mammary epithelial cells to take part in local mammary gland innate immune. In order to verify this hypothesis, goat mammary gland and isolated mammary epithelial cells (MECs) were used to explore the expression of CNP/NPR-B and their physiological roles in goat mammary gland.

\section{Results}

The results showed that goat mammary gland expressed NPR-B but not CNP. Activating NPR-B by treatment with CNP had no effect on synthesis of $\beta$-casein and lipid in goat MECs. But the expression and secretion of S100A7 in goat MECs were obviously induced by CNP/NPR-B signaling pathway. After treatment with CNP, the cGMP level in goat MECs were significantly up-regulated. Along with the upregulation of CGMP level, the phosphorylation levels of JNK and its target c-Jun also increased gradually. KT-5823 is a specific inhibitor for PKG. KT5823 remarkably inhibited the phosphorylation of JNK and cJun induced by CNP. Correspondingly, KT5823 evidently inhibited the expression and secretion of S100A7 induced by CNP. On the other hand, the expression of NPR-B and S100A7 were up-regulated in mastitis goat mammary gland. But, there were no significant difference in expression of CNP between health and mastitis goat mammary gland tissues. Goat mastitis model was established in vitro using goat MECs treated by lipopolysaccharide (LPS). LPS treatment also could increase the expression of NPR-B and NPR-B.

\section{Conclusions}

Goat mammary gland expressed NPR-B, indicating mammary gland was target organ for natriuretic peptide system. Moreover, CNP, through NPR-B/JNK/c-Jun signaling pathway to regulate the expression and secretion of S100A7 in MECs, played an important role in mammary gland innate immune.

\section{Background}

The natriuretic peptides (NPs) family, mainly including A-type natriuretic peptide (ANP), B-type natriuretic peptide (BNP) and C-type natriuretic peptide (CNP), are well known produced in cardiovascular and central nervous system [1] and play important roles in cardioprotective function, regulation of blood 
pressure and fluid balance [2]. CNP was first isolated from porcine brain [3], its function was dependent on the activation of natriuretic peptide receptor $B$ (NPR-B, also termed guanylyl cyclase-B, GC-B). NPR-B is a guanylyl cyclase receptor. Once CNP binds to NPR-B, NPR-B induces the production of cGMP, thereby activating PKG and downstream targets [4]. CNP/NPR-B signaling pathway was reported exerted multifaceted biological effects on heart failure, blood microcirculation [5], entochondrostosis [6] and even in follicular development [7]. In addition, it is reported that CNP could suppress inflammation reaction. Activation of CNP/NPR-B signaling pathway down-regulated the expression of pro-inflammatory factor including IL-1 $\beta, I L-6$ and TNF- $\alpha$, and inhibited macrophage infiltration $[8,9,10,11,12]$. Besides antiinflammation effect, CNP may possess direct effect on bacteria lipopolysaccharide biosynthesis [13] and biofilms formation $[14,15,16]$. Unlike ANP and BNP, CNP usually is regarded as an autocrine and paracrine factor to regulate local tissue function [4]. However, in goat, as an important dairy domestic animal, whether CNP/NPR-B is expressed in mammary gland, what physiological functions it has, and what its role in mammary disease has not been reported.

S100A7 (Psoriasin), which is firstly identified in the epithelial cells of human psoriasis skin $[17,18]$, is one of the antimicrobial peptide (AMP) with a strong antimicrobial activity especially against E. coli in humans [19] and bovine [20]. In goat, S100A7 was expressed in stratified squamous epithelium of the teat, gland cistern and epithelial cells of the alveolus [21]. Mastitis is an inflammatory reaction of udder tissue commonly caused by microbial infection. Pathogens pass through teat canal and then enter alveolus, resulting in intramammary infection. Based on the antibacterial and immunomodulatory activities, the expression of S100A7 in the alveolus is considered to be a critical component of the animal innate immune system and play important roles in host mammary gland defense system [22]. Many inflammatory cytokines such as IL-6, IL-17, IL-22 and TNF-a could up-regulate the expression of S100A7 $[23,24]$. However, the expression regulation mechanism of S100A7 in goat mammary gland, especially in mastitis goat mammary gland, is not clear yet. In human, the expression of S100A7 is regulated by an activator protein-1(AP-1)-responsive promoter [25]. As a subunit of AP-1, c-Jun was reported to be a target of NPs signaling $[26,27,28]$. Whereas, it is still unclear whether CNP / NPR-B is involved in the expression regulation of S100A7.

The aim of this study is to explore the expression of CNP/NPR-B and their physiological roles in goat mammary gland. The results showed that goat mammary gland alveolus and mammary epithelial cells (MECs) expressed NPR-B. CNP/NPR-B regulated the expression and secretion of S100A7 via PKG/JNK/CJun signaling pathway.

\section{Methods}

\section{Animals}

This study was approved by the Institutional Animal Ethical and welfare Committee, Northwest A\&F University, Shaanxi, China (Approval No. 2020039, Date. 2020.03.09). All animal procedures were performed under control of the Guidelines for Animal Ethical and welfare Committee, Northwest A\&F 
University. Mammary gland tissue samples of health and mastitis goats were collected from lactating Guanzhong dairy goats in Shaanxi, China. The health goats $(n=6)$ : no clinical signs, bacteriological tests negative; The mastitis goats $(n=6)$ : evident clinical signs (udders were swollen and hard, there are floccules, clots or yellow color in the milk, even stop lactation.) and bacteriological tests positive. Both of the samples from health and mastitis goats were used to make paraffin sections and quantitative PCR. Only mammary gland tissues of health goats were used to isolate MECs.

\section{Goat mammary epithelial cells (MECs) isolation and culture}

The mammary gland tissues were surgically isolated from lactating Guanzhong dairy goat. The mammary tissues were trimmed of visible fat and connective tissues and washed with PBS several times until the solution became pellucid and devoid of milk. The mammary tissues were minced into about 1 $\mathrm{mm}^{3}$ cubes and were then implanted into the $35-\mathrm{mm}$ Petri dish and were incubated at $37^{\circ} \mathrm{C}$ with saturated humidity and $5 \% \mathrm{CO}_{2}$. After 6 hours, $2 \mathrm{~mL}$ culture medium was added to the culture dish. The culture medium consisted of DMEM-F12 (Invitrogen Corporation, Waltham, MA) supplemented with $10 \%$ fetal bovine serum (Invitrogen Corporation, Waltham, MA) and $1001 . \mathrm{U} . / \mathrm{mL}$ penicillin, $100 \mu \mathrm{g} / \mathrm{mL}$ streptomycin(Invitrogen Corporation, Waltham, MA). The medium was replaced with fresh medium every $48 \mathrm{~h}$ until the cells migrated out of the tissue. About 10 days later, the cells spread across the bottom of the dish were passaged by digestion with $0.25 \%$ trypsin/EDTA. The cells were reseeded in a new $35-\mathrm{mm}$ Petri dish at a density of $2 \times 10^{5} \mathrm{cells} / \mathrm{cm}^{2}$ and cultured at $37^{\circ} \mathrm{C}$ under $5 \% \mathrm{CO}_{2}$. In present experiments, cells passaged within 9 times were used.

\section{Immunohistochemistry}

Paraffin sections were deparaffinized and hydrated in graded ethanol series before staining with the streptavidin-perosidase method. Antigens were retrieved by boiling for $15 \mathrm{~min}$ in Citrate Antigen Retrieval solution (Solarbio, China). Endogenous peroxidase was blocked by incubation in 3\% hydrogen peroxide. Then followed the instructions of the universal SP staining kit, in which the primary antibody anti-CNP (1:100), anti-NPR-B (1:100) and anti-S100A7 (1:100) (Bioss, Beijing, China) is incubated overnight at $4^{\circ} \mathrm{C}$, and the second antibody are incubated at $37^{\circ} \mathrm{C}$ for 1 hour. After incubation, sections were lightly counterstained with hematoxylin and were dehydrated and cover slipped. The immunohistochemical results were analyzed quantitatively using Image $\mathrm{J}$ 1.8.0.

\section{Immunofluorescence}

Cells were fixed for $30 \mathrm{~min}$ in $4 \%$ paraformaldehyde (Solarbio, Beijing, China), permeabilized for $15 \mathrm{~min}$ in $0.2 \%$ TritonX-100 (Sigma, St. Louis, MO), incubated for $2 \mathrm{~h}$ in blocking buffer (3\% BSA in PBS), and treated with primary antibody against CK18 (1:100, Abcam, Cambridge, MA), CK14 (1:100, Abcam, Cambridge, MA), NPR-B (1:100, Bioss, Beijing, China) overnight at $4^{\circ} \mathrm{C}$. The secondary antibody used was Goat Anti-Rabbit IgG-Alexa Fluor® 488 (1:100, Abcam, Cambridge, MA). The nuclei were stained with DAPI (Beyotime, Shanghai, China) for 5 min at room temperature. Images were captured using a fluorescence microscope (Olympus, Tokyo, Japan). 


\section{RNA extraction and reverse transcription and polymerase chain reaction}

Total RNA was extracted using RNAiso Plus (Takara Bio Inc, Otsu, Japan) according to the manufacturer's instructions. cDNA was synthesized using PrimeScript ${ }^{\mathrm{TM}} \mathrm{RT}$ Reagent Kit (Takara Corporation, Dalian). The primer sequences are shown in Supplementary Table S1. The amplified products were separated and analyzed by electrophoresis on a $1 \%$ agarose gel. The quantitative RT-PCR reactions were performed with the Fast SYBR Green Master Mix (Genstar, Beijing, China), data collection and data analysis were performed on the QuantStudio 6 Flex machine (Invitrogen Corporation, Waltham, MA) by using the GraphPad Prism 6 software. The quantitative RT-PCR parameters were as follows: $95^{\circ} \mathrm{C}$ for $2 \mathrm{~min}$, followed by 40 cycles each of $95^{\circ} \mathrm{C}$ for $15 \mathrm{~s}, 60^{\circ} \mathrm{C}$ for $30 \mathrm{~s}$, and $72^{\circ} \mathrm{Cfor} 30 \mathrm{~s}$. Relative gene expression was obtained by normalizing with GAPDH expression, calculating differences in mRNA expression as fold changes relative to expression in Control group.

\section{Western blot analysis}

Cells were lysed with RIPA buffer (Solarbio, Beijing, China) supplemented with $1 \mathrm{mM}$ phenylmethylsulfonyl fluoride (Solarbio, Beijing, China) on ice for $30 \mathrm{~min}$. Western blot was carried out with equal amounts of protein. The primary antibodies were as follows: anti-NPR-B (1:1000, Bioss, Beijing, China),anti-S100A7 (1:1000, Bioss, Beijing, China), anti-JNK (1:1000, CST, Danvers, MA), antiphospho-JNK (1:1000, CST, Danvers, MA), anti-C-Jun (1:1000, CST, Danvers, MA), anti-phospho-C-Jun (1:1000, CST, Danvers, MA), anti-GAPDH (1:1000, CST, Danvers, MA). The secondary antibodies used were goat anti-rabbit IgG-HRP(1:2000, Abcam, Cambridge, MA). The protein bands were detected with a chemiluminescence kit (Tanon, Shanghai, China).

\section{ELISA}

The cGMP and secretion of S100A7 from goat MECs was measured using ELISA. The cell lysate or cell culture medium were collected after treatment and stored at $-20^{\circ} \mathrm{C}$. The ELISA was performed using Goat cGMP ELISA kit and Goat S100A7 ELISA kit (Jianglaibio, Shanghai, China) according to manufacturer's protocol. The absorbance was measured at $450 \mathrm{~nm}$ using the microplate reader (Tecan, Tecan Group Ltd, Switzerland)

\section{Statistics}

All quantitative data are presented as mean \pm standard deviation (SD) with no less than three replicates for each experimental condition. Comparison between experimental and control groups were performed with Factorial ANOVA with the use of SPSS 10.0. A value of $p<0.05$ was considered significant difference, a value of $p<0.01$ was considered extremely significant difference.

\section{Results}




\section{Goat MECs expressed NPR-B but did not express CNP}

In order to study whether goat MECs expressed NPR-B and its ligand CNP, health goat mammary glands were used for immunohistochemical analysis. The results showed that the mammary lobules and alveolus were well developed in lactating goat mammary glands, NPR-B but not CNP positive immunoreactivity was present in the alveolus epithelial cells (Fig. 1).

To further confirm the expression of NPR-B in MECs, goat MECs were isolated and culture in vitro. Isolated goat MECs possessed typical epithelial cell morphology, including colony forming and cobblestone-like shape (Fig. 2. A). Immunofluorescence results showed that the isolated cells expressed differentiated luminal epithelial cells marker cytokeratin 18 (Fig. 2. A) but not myoepithelial cells marker cytokeratin 14 (CK14) (Fig. 2. A). Furthermore, the mRNA of $\beta$-casein could be detected by RT-PCR (Fig. 2. $B$ ) in isolated cells. These results indicated that the isolated cells were goat mammary epithelial cells. Cell growth curve result showed that the isolated goat MECs proliferated vigorously within 9 passages (Fig. 2 . C). RT-PCR results indicated that goat MECs expressed the mRNAs of NPR-B and BNP precursor (NPPB). However, the mRNAs of other two receptors NPR-A and NPR-C, and other two natriuretic peptide precursors NPPA and NPPC could not be detected (Fig. 2. D). The expression of NPR-B mRNA without NPPC mRNA was consistent with the immunohistochemical results mentioned above. Moreover, the immunofluorescence and Western-blotting results further confirmed the expression of NPR-B in goat MECs (Fig. 2. E, F).

\section{CNP induced the expression and secretion of S100A7 in Goat MECs}

Although goat MECs expressed NPR-B, the role of NPR-B in physiological function of MECs is unclear. CNP, a high affinity ligand of NPR-B, was added into MECs culture medium at different concentration. As the main functions of MECs, the effect of CNP on synthesis of $\beta$-casein and fatty acid were firstly analysis. As showed in Fig S1, CNP had no effect on mRNA expression of $\beta$-casein (Fig S1. A). The genes related to synthesis of fatty acid such as acetyl-CoA carboxylases alpha (ACACA) and sterol regulatory element binding transcription factor 1 (SREBF1) also were not effected by CNP treatment (Fig S1. A). Meanwhile, Oil Red O stained result showed that CNP did not effect the triglyceride synthesis in goat MECs (Fig S1. B). On the other hand, cell proliferation and cell cycle analysis results indicated CNP had no effect on cell proliferation of MECs (Fig S2).

Interestingly, the expression and secretion of antimicrobial peptide S100A7 in goat MECs were obviously induced by CNP treatment. Like positive control LPS, goat MECs treated by $10 \mathrm{nM}$ CNP for $6 \mathrm{~h}$, the protein expression level of S100A7 significantly increased compared with control (0 nM CNP) ( $<<0.05)$ (Fig. 3. A). $100 \mathrm{nM}$ CNP treatment for $6 \mathrm{~h}$, the protein expression level of S100A7 remarkably up-regulated compared with control $(0 \mathrm{nM} \mathrm{CNP})(\mathrm{p}<0.01)$ (Fig. 3. A). In addition to protein expression, the secretion of S100A7 from goat MECs into medium was also tested by ELISA. The results showed that like positive control LPS, $10 \mathrm{nM}$ and $100 \mathrm{nM}$ CNP treatment only for $3 \mathrm{~h}$, the secretion of S100A7 was evidently increased 
compared to control $(0 \mathrm{nM} \mathrm{CNP})(\mathrm{p}<0.01)$, and the increase in S100A7 concentration in medium was consistently maintained until treatment for $9 \mathrm{~h}$ in present experiments (Fig. 3. B). These results indicated that CNP could induce the expression and secretion of S100A7 in goat MECs.

\section{CNP activated NPR-B/JNK/C-Jun signaling pathway in goat MECs}

NPR-B is a guanylate cyclase coupled receptor. It's physiological function depends on the guanylate cyclase activity, which cyclizes GTP into cGMP. cGMP acts as the second messenger to activate the downstream signal pathway. Therefore, firstly, the change of cGMP content in goat MECs after CNP treatment was detected. After treatment with $10 \mathrm{nM}$ and $100 \mathrm{nM}$ CNP for 1- $3 \mathrm{~h}$, the cGMP level in goat MECs were significantly up-regulated compared to control $(0 \mathrm{nM} \mathrm{CNP})(\mathrm{p}<0.01)$ (Fig. 4. A). Moreover, along with the up-regulation of cGMP level, compared with control ( $0 \mathrm{nM} \mathrm{CNP})$, the phosphorylation levels of JNK also increased gradually after $100 \mathrm{nM}$ CNP treatment ( $p<0.05)$ (Fig. 4. B, C). As a target protein of JNK, after $100 \mathrm{nM}$ CNP treatment, the phosphorylation levels of c-Jun was up-regulated significantly compared with control $(0 \mathrm{nM}$ CNP) $(p<0.05)$ (Fig. 4. B, D). These results indicated that CNP could activate NPR-B/JNK/c-Jun signaling pathway in Goat MECs.

\section{PKG inhibitor KT5823 inhibited the expression and secretion of S100A7 induced by CNP in goat MECs}

Since CNP activated NPR-B/JNK/C-Jun signaling pathway in Goat MECs, it is necessary to test whether the expression and secretion of S100A7 were dependent on this signaling pathway. KT5823 is a selective inhibitor for PKG (cGMP-dependent protein kinase, PKG). As showed in Fig. 5, The adding of CNP alone could significantly increase the phosphorylation levels of JNK and c-Jun compared to control $(p<0.05)$ (Fig. 5. A). However, KT5823 remarkably inhibited the phosphorylation of JNK and c-Jun induced by CNP (Fig. 5. A). These results suggested that CNP up-regulated the phosphorylation of JNK and c-Jun by cGMP/PKG. Correspondingly, The expression level and secretion content of S100A7 were significantly increased by treatment with $100 \mathrm{nM}$ CNP alone for $6 \mathrm{~h}$ compared to control $(\mathrm{p}<0.05)$ (Fig. 5. B, C). If adding both of CNP and KT5823 simultaneously, KT5823 evidently inhibited the expression of S100A7 induced by CNP $(p<0.01)$, and the S100A7 secreted from goat MECs into medium was also downregulated compared with treatment with CNP alone ( $p<0.05)$ (Fig. 5. B, C). The inhibitory effect of KT5832 on inductive function of CNP suggested that CNP induced the expression and secretion of S100A7 in goat MECs depended on NPR-B/PKG/JNK/c-Jun signaling pathway.

\section{The expression of NPR-B and S100A7 were up-regulated in mastitis goat mammary gland}

S100A7 is an antimicrobial peptide (AMP) with antimicrobial activities for a broad spectrum of bacteria. Therefore, it is a hypothesis that CNP/NPR-B, which induced goat MECs to express and secret S100A7, maybe involved in the occurrence or prevention of mastitis in goat. In order to verify this hypothesis, the 
expression of CNP, NPR-B and S100A7 in health $(n=6)$ and mastitis $(n=6)$ goats were detected by immunohistochemistry and quantitative PCR. In health goat mammary gland, pathological examination results showed that the lobule and alveolus were well developed and completed (Fig S3). Except for CNP, both of NPR-B and S100A7 were expressed in the alveolus epithelial cells in health goat mammary gland (Fig. 6. A). But, in mastitis goat mammary gland, pathological examination results showed that the alveolus collapsed and the infiltration of blood cells could be seen in collapsed alveolus (Fig S3). The immunohistochemical results showed that the densely NPR-B and S100A7 immunoreactivity could be observed in collapsed alveolus in mastitis mammary gland (Fig. 6. A). Like in health goat, CNP could not be detected in the alveolus epithelial cells in mastitis goat mammary gland (Fig. 6. A). The average optical density (AOD) of NPR-B and S100A7 in mastitis goat mammary gland were obviously higher than that in health goat mammary gland $(p<0.01)$ (Fig. 6. B). But there were no significant difference in AOD of CNP between health and mastitis goat mammary glands ( $p>0.05)$ (Fig. 6. B). Similarly, the mRNAs of NPR-B and S100A7 in mastitis goat mammary gland tissues were apparently up-regulated compared to that in health goat $(p<0.01)$ (Fig. 6 . C). There were no significant difference in mRNA of CNP between health and mastitis goat mammary gland tissues ( $p>0.05$ ) (Fig. 6 . C). These results suggested that the expression of NPR-B and S100A7 were up-regulated in mastitis goat mammary gland.

On the other hand, goat mastitis model was established in vitro using goat MECs treated by LPS. After treatment with $5 \mu \mathrm{g} / \mathrm{mL}$ LPS for $6 \mathrm{~h}$, the mRNAs of inflammatory response related factors including IL-6, IL-1 $\beta$ and TNF-a were obviously increased compared to control $(0 \mu \mathrm{g} / \mathrm{mL}$ LPS) $(p<0.01)$ (Fig. 7. A). Meanwhile, after treatment with $5 \mu \mathrm{g} / \mathrm{mL}$ LPS for $6 \mathrm{~h}$, the secretion content of S100A7 was higher than that of control $(0 \mu \mathrm{g} / \mathrm{mL}$ LPS) $(p<0.01)$ (Fig. 7. B). This increase in S100A7 secretion was consistent until LPS treatment for $12 \mathrm{~h}$. After $24 \mathrm{~h}$ of treatment, the secretion of S100A7 began to decrease, but it was still higher than that of the control group $(0 \mu \mathrm{g} / \mathrm{mL}$ LPS) $(\mathrm{p}<0.05)$ (Fig. 7. B). For the protein expression of S100A7, it was higher than that of control $(0 \mu \mathrm{g} / \mathrm{mL}$ LPS $)(p<0.05)$ after treatment with $5 \mu \mathrm{g} / \mathrm{mL}$ LPS for $6 \mathrm{~h}, 12 \mathrm{~h}$ respectively, but there were no significant difference between $24 \mathrm{~h}$ group and control $(0 \mu \mathrm{g} / \mathrm{mL}$ LPS) ( $p>0.05)$ (Fig. 7. C). These results indicated that LPS could induce the establishment of mastitis model in vitro and induce the expression and secretion of S100A7 in goat MECs. Further, in this goat mastitis model in vitro, the expression level of NPR-B was obviously up-regulated. After treatment with 5 $\mu \mathrm{g} / \mathrm{mL}$ LPS for $6 \mathrm{~h}, 12 \mathrm{~h}, 24 \mathrm{~h}$ respectively, the expression levels of NPR-B in all of these three groups were markedly higher than that of the control group $(0 \mu \mathrm{g} / \mathrm{mL}$ LPS) $(p<0.05)$ (Fig. 7. D). These results suggested that the increase in expression of NPR-B was involved in goat mastitis.

\section{Discussion}

In goat, CNP and NPR-B were only reported mainly expressed in lung, heart, ovary and uterus $[29,30]$. In present study, the expression of CNP and NPR-B were firstly analyzed in health goat mammary gland. Immunohistochemical results showed that there was only NPR-B but not CNP positive immunoreactivity in the alveolus epithelial cells. In order to confirm this result, goat MECs were isolated and detected the expression of NPs family and their receptors. The results of RT-PCR confirmed the immunohistochemistry results that the goat MECs only expressed the mRNA of NPR-B, did not express the mRNA of NPPC. There 
are few reports about the expression of NPs family and their receptors in MECs. Previous receptor autoradiography studies were the suggestive of the existence of both NPR-A and NPR-B in rat and goat mammary gland $[31,32,33]$. In present study, the results of mRNA and protein level results provided the direct evidence for the expression of NPR-B in goat MECs. CNP has the highest affinity with NPR-B [34]. But, the goat MECs expressed BNP rather than CNP. The highest affinitive receptor for BNP is NPR-A which was not expressed in goat MECs.

Since goat MECs expressed NPR-B, the role of NPR-B in physiological function of MECs is unclear. Activating NPR-B by treatment with its ligand CNP had no effect on synthesis of $\beta$-casein and lipid. Although there are no reports on the relationship between protein or fat content in milk and CNP or other natriuretic peptides, many studies reported that CNP/NPR-B pathway regulated lipid metabolism in other cells $[35,36.37,38]$. Because CNP was added alone without other lipid matoblism regulators in present study, the involvement in lipid metabolism of CNP/NPR-B in MECs could not be excluded. Whether CNP plays a synergistic role with other regulators such as estrogen, prolactin and oxytocin in milk lipid synthesis remains to be further studied. On the other hand, CNP had no effect on proliferation of goat MECs. As for the effects of CNP on cell proliferation and apoptosis, the reports are inconsistent. Recent studies have shown that CNP could inhibit the proliferation and promote apoptosis of many types of cells, including vascular smooth muscle cells [39], renal mesangial cells [40,41], fibroblasts [42] and endothelial cells [43]. However, CNP promoted the proliferation and inhibited the apoptosis of granulosa cells [44], osteoblasts [45] and Leydig cells [46]. These indicated that CNP/NPR-B signaling pathway had cell or tissue specificity in regulating cell apoptosis and proliferation.

Interestingly, the expression and secretion of antimicrobial peptide S100A7 in goat MECs were obviously induced by CNP/NPR-B signaling pathway. Goat MECs treated by CNP alone, the protein expression level and the secretion content of S100A7 significantly increased compared with control. S100A7 is considered as a critical component of the animal innate immune system [47]. Many inflammatory cytokines such as IL-6, IL-17, IL-22, TNF-a could up-regulate the expression of S100A7 [23, 24]. The inductive effect of CNP on the expression and secretion of S100A7 was the first report in present study, leading to a hypothesis that CNP/NPR-B signaling pathway may take part in innate immune and local mammary gland defense by regulating the expression and secretion of S100A7. In order to test and verify this hypothesis, the activation of CNP/NPR-B signaling pathway was detected firstly. NPR-B is a guanylate cyclase coupled receptor. It's physiological function depends on the guanylate cyclase activity. As predicted, after treatment with CNP, the CGMP level in goat MECs were significantly up-regulated. The main cGMP effector is protein kinase G (PKG),its targets include JNK [48, 49]. Interestingly, the expression of S100A7 is regulated by an AP-1 responsive promoter [25]. C-Jun, which is an important subunit of AP-1, is the phosphorylated target of JNK. It is reported that ANP/NPR-A inhibited the phosphorylation of JNK and cJun [50]. But in present study, along with the up-regulation of cGMP level, the phosphorylation levels of JNK and its target c-Jun also increased gradually after CNP treatment. These results indicated that CNP could activate NPR-B/JNK/c-Jun signaling pathway in goat MECs. Second, whether the inductive effect of CNP on the expression and secretion of S100A7 was dependent on NPR-B/JNK/C-Jun signaling pathway? KT-5823 is a specific inhibitor for PKG. As showed in Fig. 5, KT5823 remarkably inhibited the 
phosphorylation of JNK and c-Jun induced by CNP. Correspondingly, KT5823 evidently inhibited the expression and secretion of S100A7 induced by CNP.

Mastitis is an inflammatory reaction of udder tissue commonly caused by microbial infection [51]. S100A7 is an AMP with antimicrobial activities for a broad spectrum of bacteria. CNP/NPR-B, which induced goat MECs to express and secret S100A7, may be involved in the occurrence or prevention of mastitis in goat. The expression of CNP, NPR-B and S100A7 in mammary gland tissue from health and mastitis goats were analyzed. The results suggested that the expression of NPR-B and S100A7 were upregulated in mastitis goat mammary gland. But, there were no significant difference in expression of CNP between health and mastitis goat mammary gland tissues. On the other hand, goat mastitis model was established in vitro using goat MECs treated by LPS. LPS, which is a cell wall component of Gramnegative bacteria, were widely used to induce mastitis model in vivo and in vitro [52, 53, 54, 55]. Consistent with previous reports, after treatment with LPS, the inflammatory response related factors including IL-6, IL-1 $\beta$ and TNF-a were obviously increased. Moreover, LPS could induce the expression and secretion of S100A7 in goat MECs. Similar to the results in vivo, in this goat mastitis model in vitro, the expression level of NPR-B was obviously up-regulated.

Based on these results, we speculate that CNP/NPR2 through inducing the expression and secretion of S100A7 could play the important role in innate immune and local mammary gland defense. However, the goat MECs did not express CNP. There may be two sources of CNP in goat mammary gland. First is adipose tissue in udder. Recently, many reports proclaimed that adipose tissue could express CNP [36, 56]. Cumulating evidence indicates that the communication between mammary gland and adipose tissue plays a critical role in mammary gland remodeling $[57,58,59]$. Therefore, the interaction between mammary gland and adipose tissue in udder innate immune may be the next research focus. Second is inflammatory cells infiltrated into alveolus from blood. During mastitis, inflammatory cells such as monocytes, neutrophils, T cells and macrophages invade into alveolus and expressed CNP $[60,61]$ to induce the expression and secretion of S100A7 from MECs. This possibility also needs further study.

\section{Conclusion}

In conclusion, goat mammary gland expressed one of natriuretic peptide receptors NPR-B, indicating mammary gland maybe a target organ for natriuretic peptide system. Moreover, CNP, through NPR$\mathrm{B} / \mathrm{JNK} / \mathrm{C}-\mathrm{Jun}$ signaling pathway to regulate the expression and secretion of S100A7 in MECs, plays an important role in local mammary gland innate immune.

\section{Abbreviations}

NPs: natriuretic peptides

ANP: A-type natriuretic peptide

BNP: B-type natriuretic peptide 
CNP: C-type natriuretic peptide

NPR-A: natriuretic peptide receptor A

NPR-B: natriuretic peptide receptor B

NPR-C: natriuretic peptide receptor C

GC-B: guanylyl cyclase-B

MECs: mammary epithelial cells

LPS: lipopolysaccharide

AP-1: activator protein-1

IL-1ßninterleukin-1 $\beta$

IL-6: interleukin-6

TNF-altumor necrosis factor-a

JNKワc-Jun N-terminal kinase

PKG: protein kinase $\mathrm{G}$

\section{Declarations}

\section{Availability of data and materials}

The datasets generated and/or analysed during the current study are available in the [Figshare] repository, [https://doi.org/10.6084/m9.figshare.16968445.v1].

\section{Competing interests}

The authors declare that they have no competing interests.

\section{Funding}

This research was funded by National Natural Science Foundation of China, grant number 31772818 .

\section{Authors' contributions}

$F M, Y Y$ and $M Y$ performed the experiment. $Y Y, Z K$ and $W Q$ analyzed and interpreted the data. WQ, $P M$ and $Z X$ were major contributor in writing the manuscript. WQ and MB support to the financial cost throughout the experiment and generate the ideas. All authors read and approved the final manuscript. 
Acknowledgements

Not applicable

\section{References}

1. Xu M, Liu X, Li P, Yang Y, Zhang W, Zhao S, Zeng Y, Zhou X, Zeng LH, Yang G. Modified Natriuretic Peptides and their Potential Role in Cancer Treatment. Biomed J. 2021; S2319-4170(21)00085-8. doi: 10.1016/j.bj.2021.06.007.

2. Kato J. Natriuretic peptides and neprilysin inhibition in hypertension and hypertensive organ damage. Peptides. 2020;132:170352. doi: 10.1016/j.peptides.2020.170352.

3. Sudoh T, Minamino N, Kangawa K, Matsuo H. C-type natriuretic peptide (CNP): a new member of natriuretic peptide family identified in porcine brain. Biochem Biophys Res Commun. 1990;168(2):863-70. doi: 10.1016/0006-291x(90)92401-k.

4. Moyes AJ, Hobbs AJ. C-type Natriuretic Peptide: A Multifaceted Paracrine Regulator in the Heart and Vasculature.Int J Mol Sci. 2019;20(9):2281. doi: 10.3390/ijms20092281.

5. Špiranec K, Chen W, Werner F, Nikolaev VO, Naruke T, Koch F, Werner A, Eder-Negrin P, DiéguezHurtado R, Adams RH, Baba HA, Schmidt H, Schuh K, Skryabin BV, Movahedi K, Schweda F, Kuhn M. Endothelial C-Type Natriuretic Peptide Acts on Pericytes to Regulate Microcirculatory Flow and Blood Pressure. Circulation.2018;138(5):494-508.doi:10.1161/CIRCULATIONAHA.117.03338.

6. Yamanaka S, Nakao K, Koyama N, Isobe Y, Ueda Y, Kanai Y, Kondo E, Fujii T, Miura M, Yasoda A, Nakao K, Bessho K. Circulatory CNP Rescues Craniofacial Hypoplasia in Achondroplasia. J Dent Res. 2017;96(13):1526-1534. doi: 10.1177/0022034517716437.

7. Zhang M, Su YQ, Sugiura K, Xia G, Eppig JJ. Granulosa cell ligand NPPC and its receptor NPR2 maintain meiotic arrest in mouse oocytes. Science. 2010;330(6002):366-9. doi: 10.1126/science. 1193573 .

8. Kimura T, Nojiri T, Hino J, Hosoda H, Miura K, Shintani Y, Inoue M, Zenitani M, Takabatake H, Miyazato $\mathrm{M}$, Okumura $\mathrm{M}$, Kangawa $\mathrm{K}$. C-type natriuretic peptide ameliorates pulmonary fibrosis by acting on lung fibroblasts in mice. Respir Res. 2016;17:19. doi: 10.1186/s12931-016-0335-6.

9. Chen G, Song X, Yin Y, Xia S, Liu Q, You G, Zhao L, Zhou H. C-type natriuretic peptide prevents kidney injury and attenuates oxidative and inflammatory responses in hemorrhagic shock. Amino Acids. 2017;49(2):347-354. doi: 10.1007/s00726-016-2367-0.

10. Day A, Jameson Z, Hyde C, Simbi B, Fowkes R, Lawson C. C-Type Natriuretic Peptide (CNP) Inhibition of Interferon-y-Mediated Gene Expression in Human Endothelial Cells In Vitro. Biosensors (Basel). 2018;8(3):86. doi: 10.3390/bios8030086.

11. Bae CR, Hino J, Hosoda H, Miyazato M, Kangawa K. C-type natriuretic peptide (CNP) in endothelial cells attenuates hepatic fibrosis and inflammation in non-alcoholic steatohepatitis. Life Sci. 2018;209:349-356. doi: 10.1016/j.Ifs.2018.08.031. 
12. Mei C, Kang Y, Zhang C, He C, Liao A, Huang D. C-Type Natriuretic Peptide Plays an Anti-Inflammatory Role in Rat Epididymitis Induced by UPEC. Front Cell Infect Microbiol. 2021;11:711842. doi: 10.3389/fcimb.2021.711842.

13. Veron W, Lesouhaitier O, Pennanec X, Rehel K, Leroux P, Orange N, Feuilloley MG. Natriuretic peptides affect Pseudomonas aeruginosa and specifically modify lipopolysaccharide biosynthesis. FEBS J. 2007;274(22):5852-64. doi: 10.1111/j.1742-4658.2007.06109.x.

14. Gannesen AV, Lesouhaitier O, Racine PJ, Barreau M, Netrusov Al, Plakunov VK, Feuilloley MGJ. Regulation of Monospecies and Mixed Biofilms Formation of Skin Staphylococcus aureus and Cutibacterium acnes by Human Natriuretic Peptides. Front Microbiol. 2018;9:2912. doi: 10.3389/fmicb.2018.02912.

15. Desriac F, Clamens T, Rosay T, Rodrigues S, Tahrioui A, Enault J, Roquigny L, Racine PJ, Taupin L, Bazire A, Dufour A, Leprince J, Bouffartigues E, Chevalier S, Feuilloley MGJ, Lesouhaitier O. Different Dose-Dependent Modes of Action of C-Type Natriuretic Peptide on Pseudomonas aeruginosa Biofilm Formation. Pathogens. 2018;7(2):47. doi: 10.3390/pathogens7020047.

16. Lesouhaitier O, Clamens T, Rosay T, Desriac F, Louis M, Rodrigues S, Gannesen A, Plakunov VK, Bouffartigues E, Tahrioui A, Bazire A, Dufour A, Cornelis P, Chevalier S, Feuilloley MGJ. Host Peptidic Hormones Affecting Bacterial Biofilm Formation and Virulence. J Innate Immun. 2019;11(3):227241. doi: $10.1159 / 000493926$.

17. Celis JE, Crüger D, Kiil J, Lauridsen JB, Ratz G, Basse B, Celis A. Identification of a group of proteins that are strongly up-regulated in total epidermal keratinocytes from psoriatic skin. FEBS Lett. 1990;262(2):159-64. doi: 10.1016/0014-5793(90)80179-m.

18. Madsen P, Rasmussen HH, Leffers H, Honoré B, Dejgaard K, Olsen E, Kiil J, Walbum E, Andersen AH, Basse B. Molecular cloning, occurrence, and expression of a novel partially secreted protein "psoriasin" that is highly up-regulated in psoriatic skin. J Invest Dermatol. 1991;97(4):701-12. doi: 10.1111/1523-1747.ep12484041.

19. Gläser R, Harder J, Lange H, Bartels J, Christophers E, Schröder JM. Antimicrobial psoriasin (S100A7) protects human skin from Escherichia coli infection. Nat Immunol. 2005;6(1):57-64. doi: 10.1038/ni1142.

20. Regenhard P, Leippe M, Schubert S, Podschun R, Kalm E, Grötzinger J, Looft C. Antimicrobial activity of bovine psoriasin. Vet Microbiol. 2009;136(3-4):335-40. doi: 10.1016/j.vetmic.2008.12.001.

21. Zhang GW, Lai SJ, Yoshimura Y, Isobe N. Messenger RNA expression and immunolocalization of psoriasin in the goat mammary gland and its milk concentration after an intramammary infusion of lipopolysaccharide. Vet J. 2014;202(1):89-93. doi: 10.1016/j.tvjl.2014.06.013.

22. Kumar R, Ali SA, Singh SK, Bhushan V, Mathur M, Jamwal S, Mohanty AK, Kaushik JK, Kumar S. Antimicrobial Peptides in Farm Animals: An Updated Review on Its Diversity, Function, Modes of Action and Therapeutic Prospects. Vet Sci. 2020;7(4):206. doi: 10.3390/vetsci7040206.

23. Yumine A, Tsuji G, Furue M. Selective PPARa agonist pemafibrate inhibits TNF-a-induced S100A7 upregulation in keratinocytes. J Dermatol Sci. 2020;99(1):69-72. doi: 
10.1016/j.jdermsci.2020.05.005.

24. Zheng H, Gu L, Wang Z, Zhou H, Zhang C, Teng X, Hu Z, Wei X, Liu X, Zeng F, Zhao Q, Hao Y, Hu Y, Wang X, Hu J, Yu J, Wu W, Zhou Y, Cui K, Huang N, Li J. Establishing Transcription Profile of Psoriasiform Cutaneous In Vitro using HaCaT Cells Stimulated with Combination of Cytokines. J Vis Exp. 2021;(169). doi: 10.3791/61537.

25. Semprini S, Capon F, Bovolenta S, Bruscia E, Pizzuti A, Fabrizi G, Schietroma C, Zambruno G, Dallapiccola B, Novelli G. Genomic structure, promoter characterisation and mutational analysis of the S100A7 gene: exclusion of a candidate for familial psoriasis susceptibility. Hum Genet. 1999;104(2):130-4. doi: 10.1007/s004390050925.

26. Mitkiewicz M, Kuropatwa M, Kurowska E, Gorczyca WA. Different effects of soluble and particulate guanylyl cyclases on expression of inflammatory cytokines in rat peripheral blood mononuclear cells. Immunobiology. 2011; 216(3):423-30. doi: 10.1016/j.imbio.2010.06.006.

27. Lane ML, Santana O, Frost CD, Nguyen J, Guerrero J, Skelton WP 4th, Skelton M, Vesely DL. Cardiac hormones are c-Jun-N-terminal kinase 2-inhibiting peptides. Anticancer Res. 2012;32(3):721-5.

28. Manimala NJ, Frost CD, Lane ML, Higuera M, Beg R, Vesely DL. Cardiac hormones target nuclear oncogenes c-Fos and c-Jun in carcinoma cells. Eur J Clin Invest. 2013;43(11):1156-62. doi: 10.1111/eci.12153.

29. Peng JY, Xin HY, Han P, Zhao HB, Bai L, An XP, Cao BY. Identification and gene expression analyses of natriuretic peptide system in the ovary of goat (Capra hircus). Gene. 2013;524(2):105-13. doi: 10.1016/j.gene.2013.04.054.

30. Öztop M, Cinar K, Turk S. Immunolocalization of natriuretic peptides and their receptors in goat (Capra hircus) heart. Biotech Histochem. 2018;93(6):389-404. doi: 10.1080/10520295.2018.1425911.

31. Nakao K, Ogawa Y, Suga S, Imura H. Molecular biology and biochemistry of the natriuretic peptide system. II: Natriuretic peptide receptors. J Hypertens. 1992;10(10):1111-4. doi: 10.1097/00004872199210000-00002.

32. Cvek K, Gerstberger R, Schütz H, Olsson K. The goat mammary gland as a target organ for atrial natriuretic peptide. Acta Physiol Scand. 1997;160(1):9-14. doi: 10.1046/j.1365-201X.1997.00124.x.

33. Cvek K, Ridderstråle $Y$, Gerstberger R. Functional receptors for atrial natriuretic peptide in the rat mammary gland during lactation. Endocrinology. 1998;139(5):2615-21. doi:

10.1210/endo.139.5.5996.

34. Pandey KN. Molecular Signaling Mechanisms and Function of Natriuretic Peptide Receptor-A in the Pathophysiology of Cardiovascular Homeostasis. Front Physiol. 2021;12:693099. doi: 10.3389/fphys.2021.693099. eCollection 2021.

35. Glöde A, Naumann J, Gnad T, Cannone V, Kilic A, Burnett JC Jr, Pfeifer A. Divergent effects of a designer natriuretic peptide CD-NP in the regulation of adipose tissue and metabolism. Mol Metab. 2017;6(3):276-287. doi: 10.1016/j.molmet.2016.12.010. eCollection 2017 Mar. 
36. Bae CR, Hino J, Hosoda H, Son C, Makino H, Tokudome T, Tomita T, Hosoda K, Miyazato M, Kangawa K. Adipocyte-specific expression of C-type natriuretic peptide suppresses lipid metabolism and adipocyte hypertrophy in adipose tissues in mice fed high-fat diet. Sci Rep. 2018;8(1):2093. doi: 10.1038/s41598-018-20469-z.

37. Botigelli RC, Razza EM, Pioltine EM, Fontes PK, Schwarz KRL, Leal CLV, Nogueira MFG.

Supplementing in vitro embryo production media by NPPC and sildenafil affect the cytoplasmic lipid content and gene expression of bovine cumulus-oocyte complexes and embryos. Reprod Biol. 2018;18(1):66-75. doi: 10.1016/j.repbio.2018.01.004.

38. Schmid A, Albrecht J, Brock J, Koukou M, Arapogianni E, Schäffler A, Karrasch T. Regulation of natriuretic peptides postprandially in vivo and of their receptors in adipocytes by fatty acids in vitro. Mol Cell Endocrinol. 2018;473:225-234. doi: 10.1016/j.mce.2018.01.023.

39. Hutchinson HG, Trindade PT, Cunanan DB, Wu CF, Pratt RE. Mechanisms of natriuretic-peptideinduced growth inhibition of vascular smooth muscle cells. Cardiovasc Res. 1997;35(1):158-67. doi: 10.1016/s0008-6363(97)00086-2.

40. Huang BY, Hu P, Zhang DD, Jiang GM, Liu SY, Xu Y, Wu YF, Xia X, Wang Y. C-type natriuretic peptide suppresses mesangial proliferation and matrix expression via a MMPs/TIMPs-independent pathway in vitro. J Recept Signal Transduct Res. 2017;37(4):355-364. doi:

10.1080/10799893.2017.1286674.

41. Luo HH, Wu C, Hu P, Wu YF, Zhang DD, Liu SY, Jiang GM, Xu Y, Wu Y, Wang JJ, Liu FF, Wei W, Hu B. Receptor signaling and neutral endopeptidase are involved in the resistance of C-type natriuretic peptide to human mesangial proliferation and collagen-IV expression. J Investig Med. 2018;66(5):19. doi: 10.1136/jim-2017-000533.

42. Soeki T, Kishimoto I, Okumura H, Tokudome T, Horio T, Mori K, Kangawa K. C-type natriuretic peptide, a novel antifibrotic and antihypertrophic agent, prevents cardiac remodeling after myocardial infarction. J Am Coll Cardiol. 2005;45(4):608-16. doi: 10.1016/j.jacc.2004.10.067.

43. Suenobu N, Shichiri M, Iwashina M, Marumo F, Hirata Y. Natriuretic peptides and nitric oxide induce endothelial apoptosis via a cGMP-dependent mechanism. Arterioscler Thromb Vasc Biol. 1999;19(1):140-6. doi: 10.1161/01.atv.19.1.140.

44. Xi G, Wang W, Fazlani SA, Yao F, Yang M, Hao J, An L, Tian J. C-type natriuretic peptide enhances mouse preantral follicle growth. Reproduction. 2019;157(5):445-455. doi: 10.1530/REP-18-0470.

45. Lenz A, Bennett M, Skelton WP 4th, Vesely DL. Vessel dilator and C-type natriuretic peptide enhance the proliferation of human osteoblasts. Pediatr Res. 2010;68(5):405-8. doi: 10.1203/PDR.0b013e3181ef7636.

46. Yang L, Lei L, Zhao Q, Gong Y, Guan G, Huang S. C-Type Natriuretic Peptide/Natriuretic Peptide Receptor 2 Is Involved in Cell Proliferation and Testosterone Production in Mouse Leydig Cells. World J Mens Health. 2019;37(2):186-198. doi: 10.5534/wjmh.180041.

47. Chessa C, Bodet C, Jousselin C, Wehbe M, Lévêque N, Garcia M. Antiviral and Immunomodulatory Properties of Antimicrobial Peptides Produced by Human Keratinocytes. Front Microbiol. 
2020;11:1155. doi: 10.3389/fmicb.2020.01155. eCollection 2020.

48. Lee ML, Sulistyowati E, Hsu JH, Huang BY, Dai ZK, Wu BN, Chao YY, Yeh JL. KMUP-1 Ameliorates Ischemia-Induced Cardiomyocyte Apoptosis through the NO-cGMP-MAPK Signaling Pathways. Molecules. 2019;24(7):1376. doi: 10.3390/molecules24071376.

49. Ren Y, Zheng J, Yao X, Weng G, Wu L. Essential role of the cGMP/PKG signaling pathway in regulating the proliferation and survival of human renal carcinoma cells. Int $\mathrm{J}$ Mol Med. 2014;34(5):1430-8. doi: 10.3892/ijmm.2014.1925.

50. Tripathi S, Pandey KN. Guanylyl cyclase/natriuretic peptide receptor-A signaling antagonizes the vascular endothelial growth factor-stimulated MAPKs and downstream effectors AP-1 and CREB in mouse mesangial cells. Mol Cell Biochem. 2012;368(1-2):47-59. doi: 10.1007/s11010-012-1341-8.

51. Menzies P. Udder Health for Dairy Goats. Vet Clin North Am Food Anim Pract. 2021;37(1):149-174. doi: 10.1016/j.cvfa.2020.12.002.

52. Cao D, Luo J, Zang W, Chen D, Xu H, Shi H, Jing X. Gamma-Linolenic Acid Suppresses NF-kappabeta Signaling via CD36 in the Lipopolysaccharide-Induced Inflammatory Response in Primary Goat Mammary Gland Epithelial Cells. Inflammation. 2016;39(3):1225-37. doi: 10.1007/s10753-0160358-7.

53. Bulgari O, Dong X, Roca AL, Caroli AM, Loor JJ. Innate immune responses induced by lipopolysaccharide and lipoteichoic acid in primary goat mammary epithelial cells. J Anim Sci Biotechnol. 2017;8:29. doi: 10.1186/s40104-017-0162-8.

54. Shinozuka Y, Kawai K, Sato R, Higashitani A, Ueno D, Okita M, Isobe N. Effect of intramammary lipopolysaccharide infusion on milk pH of uninfused udder in goat. J Vet Med Sci. 2018;80(8):12871290. doi: 10.1292/jvms.18-0280.

55. Purba FY, Nii T, Yoshimura Y, Isobe N. Short communication: Production of antimicrobial peptide S100A8 in the goat mammary gland and effect of intramammary infusion of lipopolysaccharide on S100A8 concentration in milk. J Dairy Sci. 2019;102(5):4674-4681. doi: 10.3168/jds.2018-15396.

56. Rukavina Mikusic NL, Kouyoumdzian NM, Puyó AM, Fernández BE, Choi MR. Role of natriuretic peptides in the cardiovascular-adipose communication: a tale of two organs. Pflugers Arch. 2021; doi: 10.1007/s00424-021-02596-1.

57. Gao W, Gao Z, Pu S, Dong Y, Xu X, Yang X, Zhang Y, Fang K, Li J, Yu W, Sun N, Hu L, Xu Q, Cheng Z, Gao Y. The Underlying Regulated Mechanisms of Adipose Differentiation and Apoptosis of Breast Cells after Weaning. Curr Protein Pept Sci. 2019;20(7):696-704. doi:

$10.2174 / 1389203720666190124161652$.

58. Wang QA, Scherer PE. Remodeling of Murine Mammary Adipose Tissue during Pregnancy, Lactation, and Involution. J Mammary Gland Biol Neoplasia. 2019;24(3):207-212. doi: 10.1007/s10911-01909434-2.

59. Coradini D, Gambazza S, Oriana S, Ambrogi F. Gene expression profile of normal breast tissue and body mass index. Breast Cancer. 2021;28(2):488-495. doi: 10.1007/s12282-020-01183-Z. 
60. Cabiati M, Sabatino L, Caruso R, Caselli C, Prescimone T, Giannessi D, Del Ry S. Gene expression of C-type natriuretic peptide and of its specific receptor NPR-B in human leukocytes of healthy and heart failure subjects. Peptides. 2012;37(2):240-6. doi: 10.1016/j.peptides.2012.07.026.

61. Fu S, Ping P, Wang F, Luo L. Synthesis, secretion, function, metabolism and application of natriuretic peptides in heart failure. J Biol Eng. 2018;12:2. doi: 10.1186/s13036-017-0093-0.

\section{Figures}

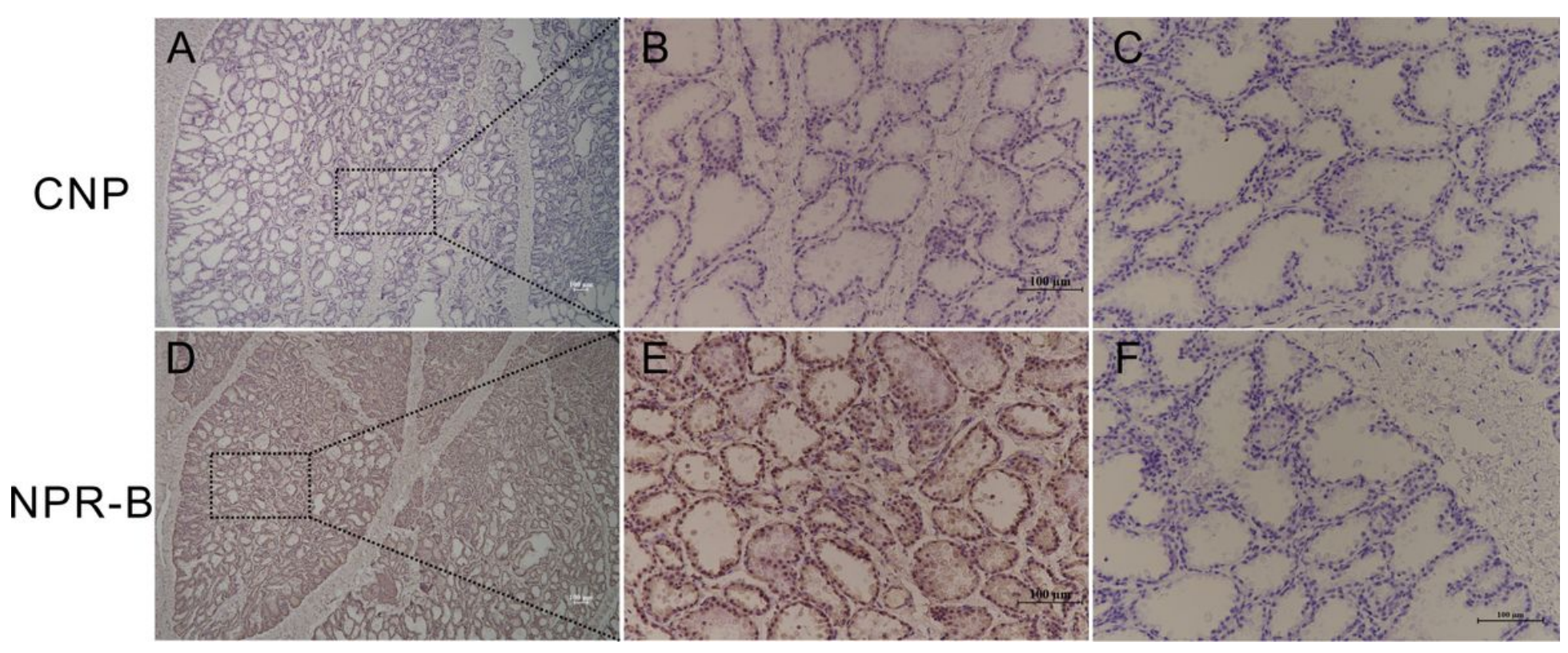

\section{Figure 1}

Representative images of immunohistochemistry in health goat mammary gland showing the expression of NPR-B but not CNP in alveolus. A-C, Immunohistochemical results of CNP. D-F, Immunohistochemical results of NPR-B. C, F, Negative control. Bar=100 $\mu \mathrm{m}$. 
A

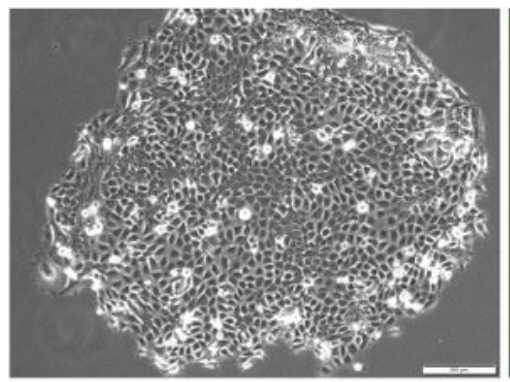

B
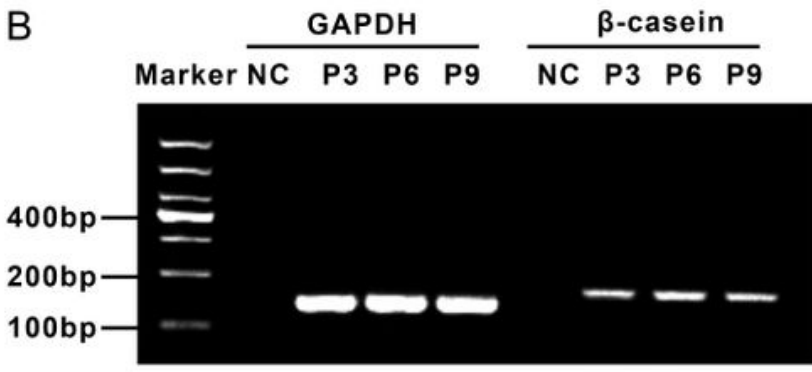

C

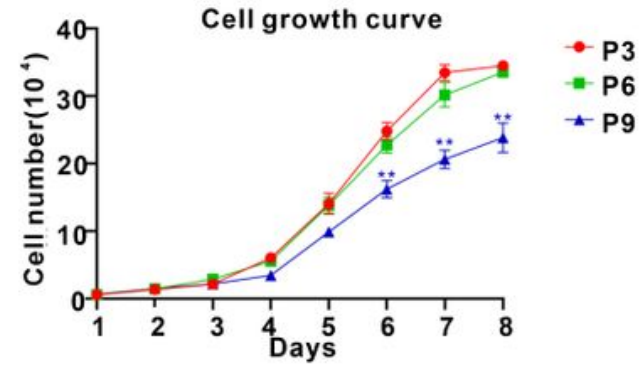

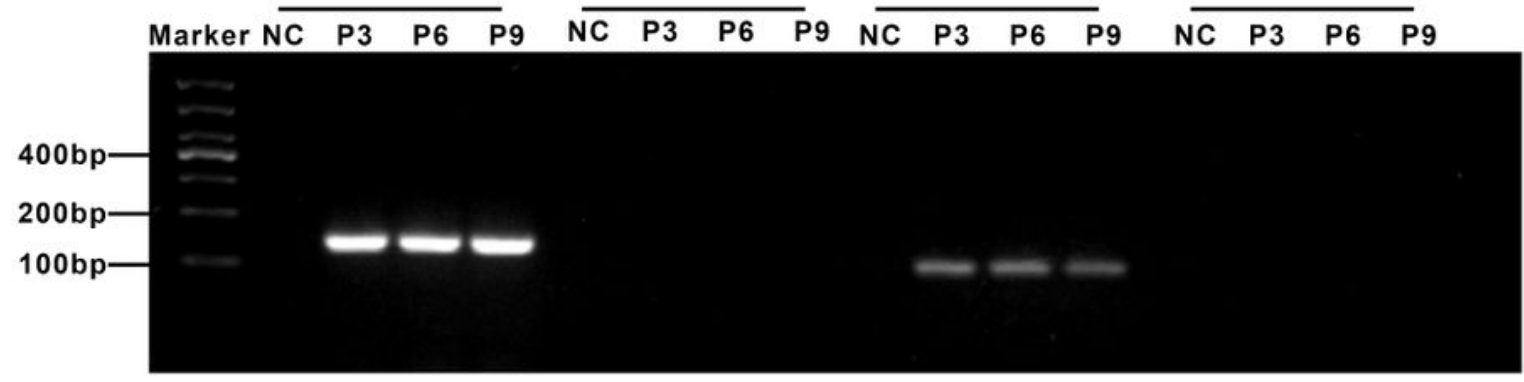

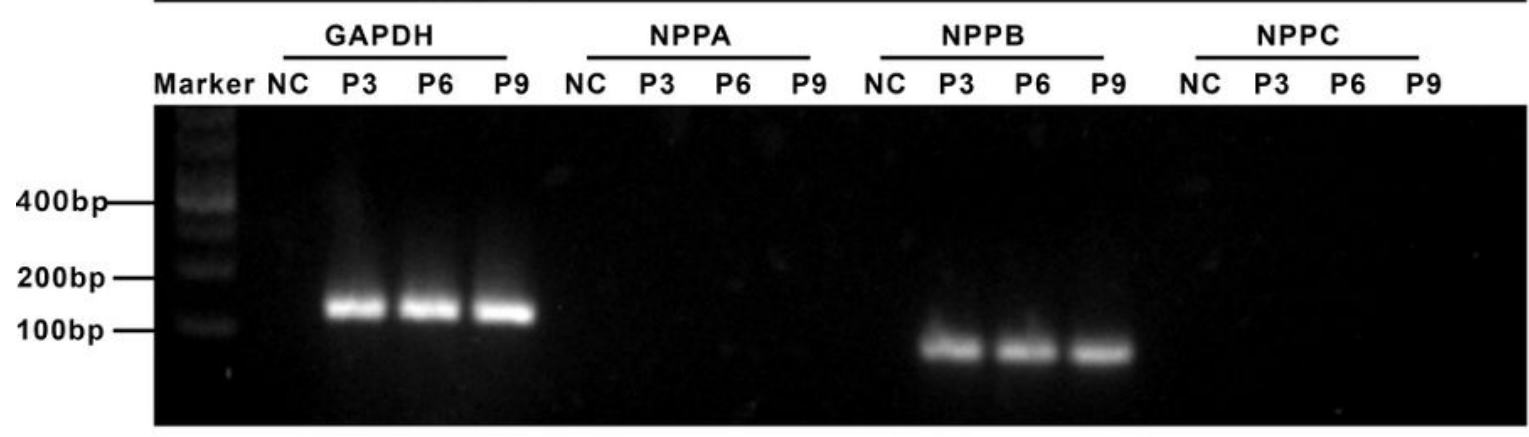

E

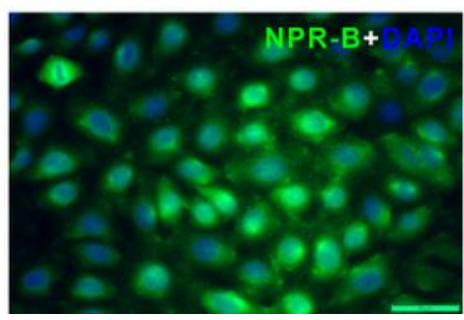

F

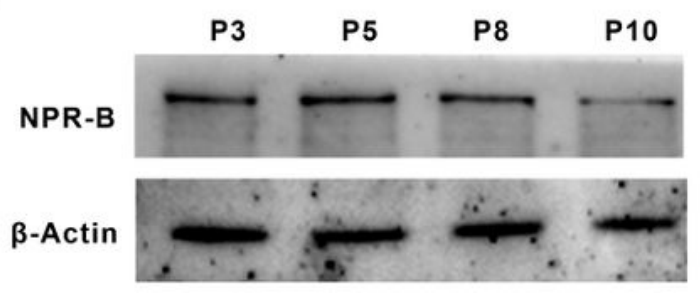

Figure 2

Characterization of goat MECs and the expression of natriuretic peptides and natriuretic peptide receptors in goat MECs. A, Characterization of goat MECs. Left, morphology of the isolated goat MECs (P5); middle, immunofluorescence result of CK18 in goat MECs; right, immunofluorescence result of CK14 in goat MECs. B, Goat MECs at passage 3, 6, 9 expressed $\beta$-casein detected by RT-PCR. C, Cell growth curve of goat MECs at passage 3, 6, 9. D, Goat MECs at passage 3, 6, 9 expressed NPPB mRNA and NPR-B mRNA, 
but not NPPA, NPPC, NPR-A and NPR-C mRNA detected by RT-PCR. E, Immunofluorescence result of NPRB in goat MECs. F, Goat MECs at passage 3, 6, 9 expressed NPR-B detected by western-bloting.

A

\section{Control LPS 10nM CNP 100nM CNP}

S100A7

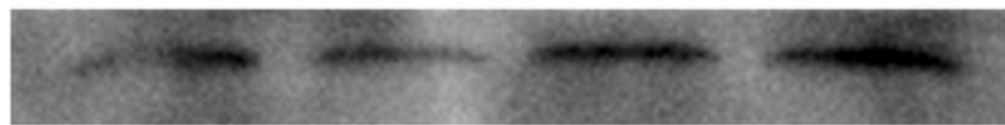

GAPDH

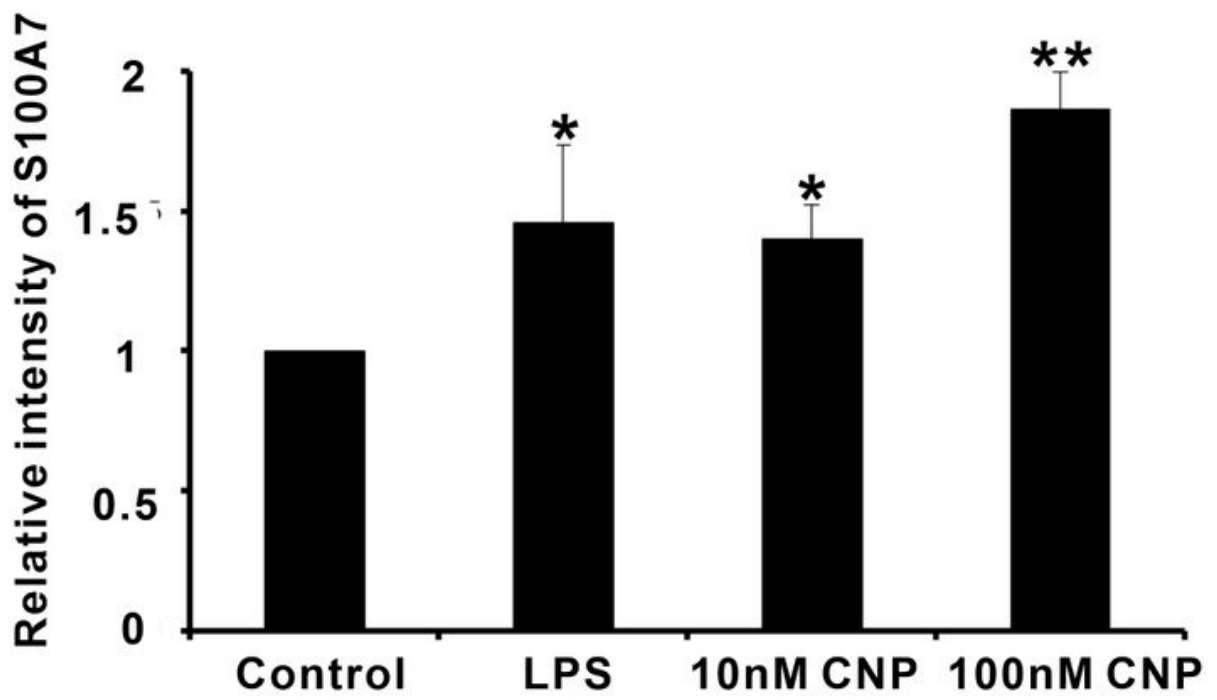

B

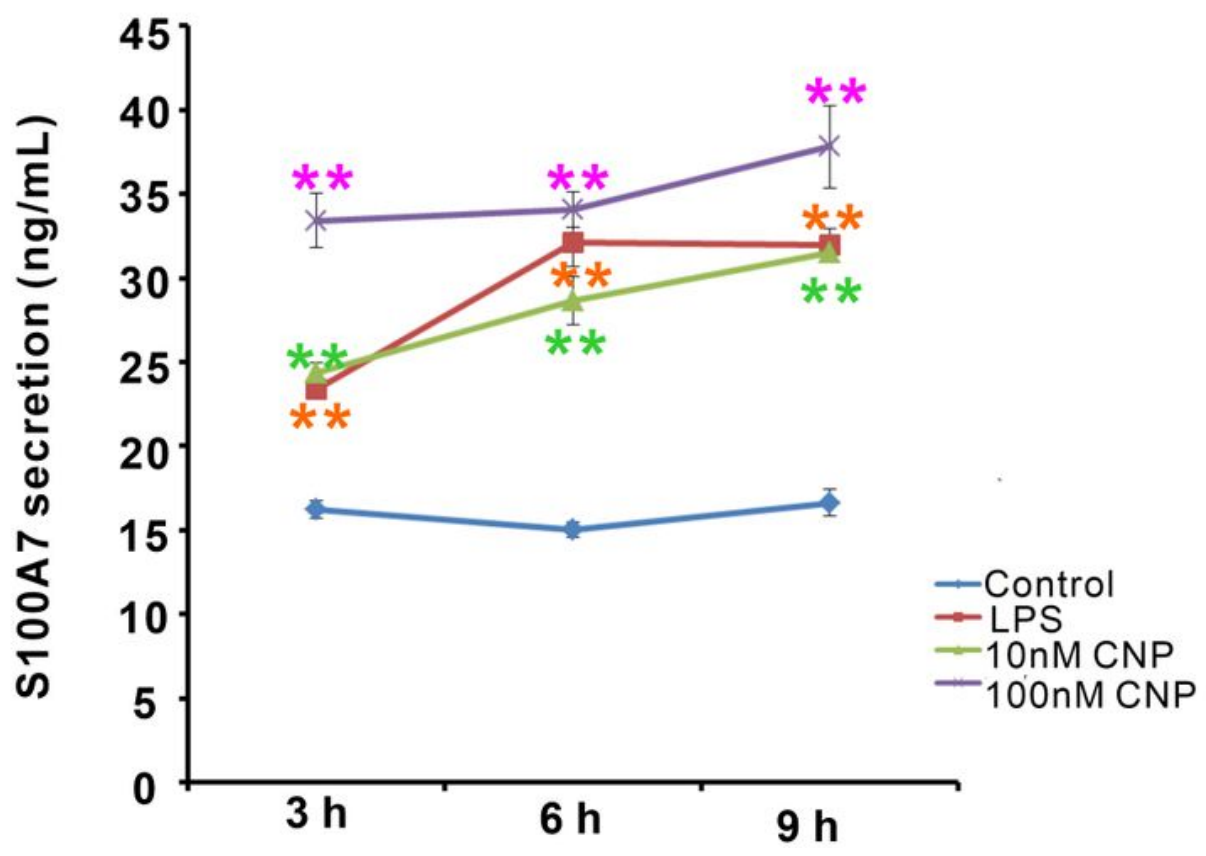

Figure 3

CNP induced the expression and secretion of S100A7 in goat MECs. A, Western-blotting results showed the protein expression level of S100A7 in goat MECs after treatment by LPS, $10 \mathrm{nM}$ CNP and $100 \mathrm{nM}$ CNP respectively for $6 \mathrm{~h}$. B, ELISA results showed the S100A7 concentration in medium in which goat MECs 
were cultured and treated by LPS, 10 nM CNP and 100 nM CNP respectively for 6 h. *: $p<0.05$ (compared to control); **: $\mathrm{p}<0.01$ (compared to control).

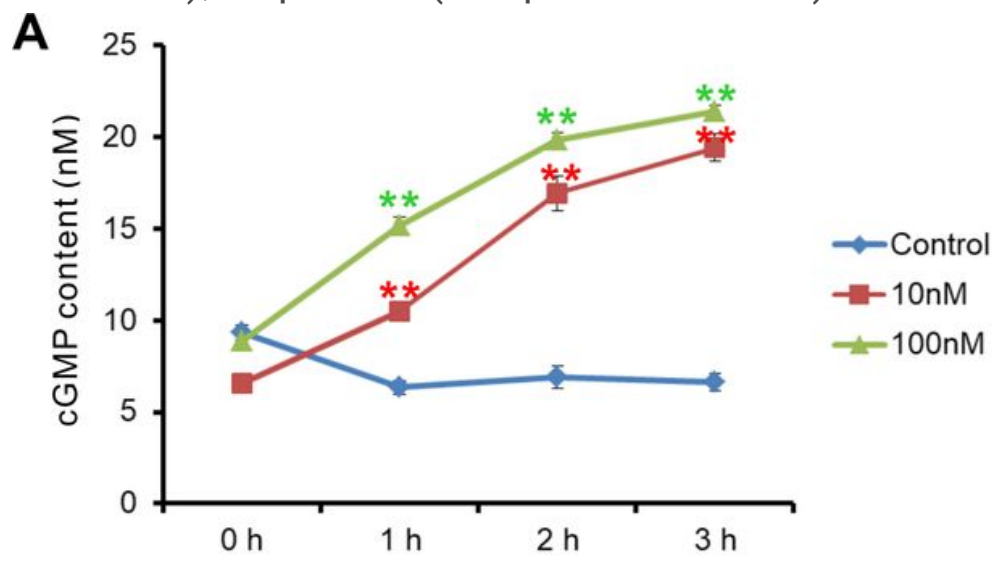

B
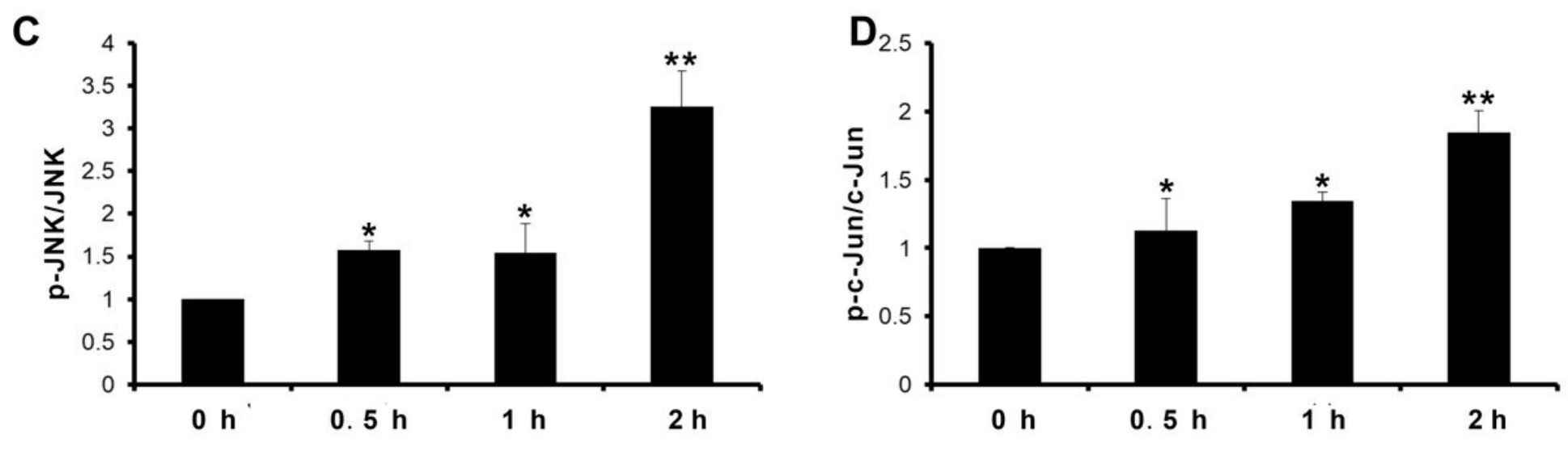

Figure 4

CNP activated NPR-B/JNK/c-Jun signaling pathway in goat MECs. A, ELISA results showed the cGMP content in goat MECs after treatment by $0 \mathrm{nM}$ (control), $10 \mathrm{nM}$ and $100 \mathrm{nM} \mathrm{CNP}$ for $0 \mathrm{~h}, 1 \mathrm{~h}, 2 \mathrm{~h}$ and $3 \mathrm{~h}$ respectively. B, The phosphorylation levels of JNK and c-Jun in goat MECs after treatment by $0 \mathrm{nM}$ (control), $10 \mathrm{nM}$ and $100 \mathrm{nM}$ CNP for $0 \mathrm{~h}, 0.5 \mathrm{~h}, 1 \mathrm{~h}$ and $2 \mathrm{~h}$ respectively detected by western-bloting. C, The quantitative analysis results of relative phosphorylation level of JNK in goat MECs after treatment by $0 \mathrm{nM}$ (control), $10 \mathrm{nM}$ and $100 \mathrm{nM}$ CNP for $0 \mathrm{~h}, 0.5 \mathrm{~h}, 1 \mathrm{~h}$ and $2 \mathrm{~h}$ respectively. D, The quantitative analysis results of relative phosphorylation level of c-Jun in goat MECs after treatment by $0 \mathrm{nM}$ (control), $10 \mathrm{nM}$ and $100 \mathrm{nM}$ CNP for $0 \mathrm{~h}, 0.5 \mathrm{~h}, 1 \mathrm{~h}$ and $2 \mathrm{~h}$ respectively. *: $\mathrm{p}<0.05$ (compared to control); $* \star \mathrm{p}$ < 0.01 (compared to control). 

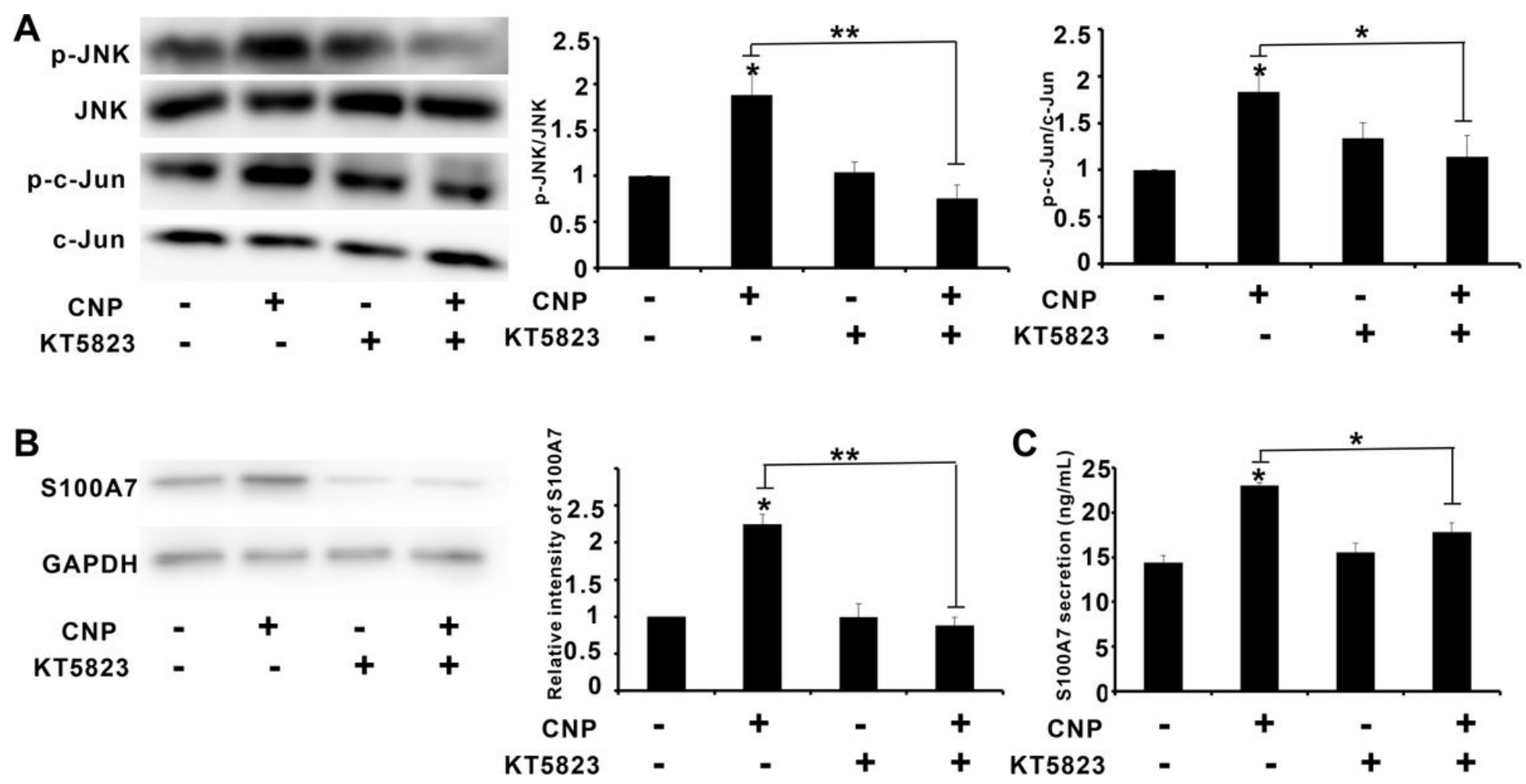

Figure 5

PKG inhibitor KT5823 inhibited the expression and secretion of S100A7 induced by CNP in goat MECs. A, The western-blotting and quantitative analysis results of relative phosphorylation level of JNK and c-Jun in goat MECs after treatment with $100 \mathrm{nM}$ CNP alone or both of $100 \mathrm{nM}$ CNP and $1 \mu \mathrm{M}$ KT5823 simultaneously for $2 \mathrm{~h}$. B, The western-blotting and quantitative analysis results of S100A7 expression in goat MECs after treatment with $100 \mathrm{nM}$ CNP alone or both of $100 \mathrm{nM}$ CNP and $1 \mu \mathrm{M} \mathrm{KT5823}$ simultaneously for $6 \mathrm{~h}$. C, ELISA results showed the S100A7 concentration in medium in which goat MECs were cultured and treated by $100 \mathrm{nM}$ CNP alone or both of $100 \mathrm{nM}$ CNP and $1 \mu \mathrm{M} \mathrm{KT5823}$ simultaneously for 6 h. *: $p<0.05$ (compared to control or CNP alone group); $* *$ : $<0.01$ (compared to control or CNP alone group). 


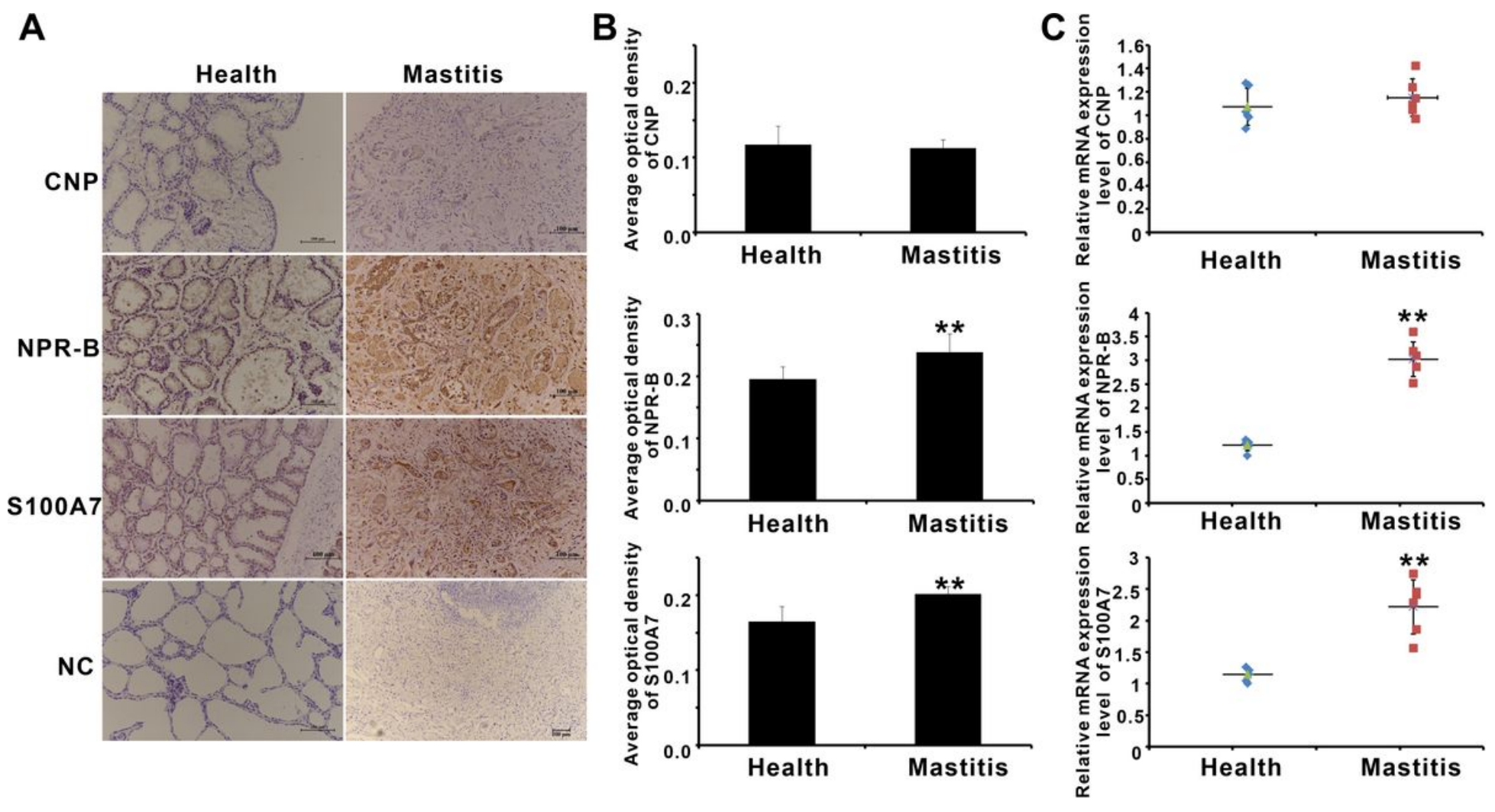

Figure 6

The expression of CNP, NPR-B and S100A7 in health and mastitis goat mammary glands. A, Representative images of immunohistochemistry showing the expression of CNP, NPR-B and S100A7 in health and mastitis goat mammary glands. B, Quantitative analysis of average optical density (AOD) of CNP, NPR-B and S100A7 in health and mastitis goat mammary glands. C, Quantitative PCR results showing the mRNAs expression level of CNP, NPR-B and S100A7 in health and mastitis goat mammary glands. ${ }^{*} p<0.05$ (compared to health group); $* *$ : $<0.01$ (compared to health group). 
A

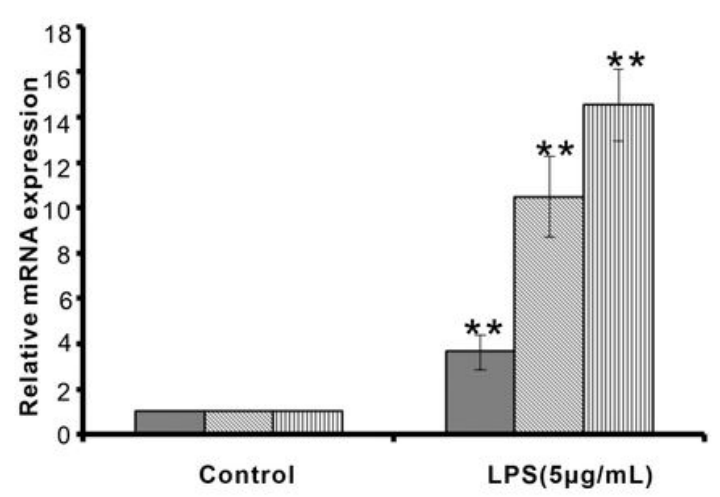

C

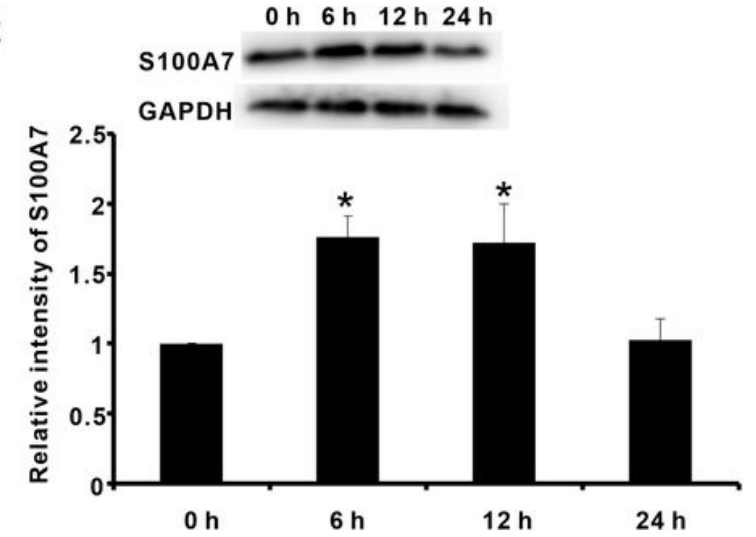

口IL-6

$\square$ IL-1 $\beta$

$\square T N F-\alpha$
B
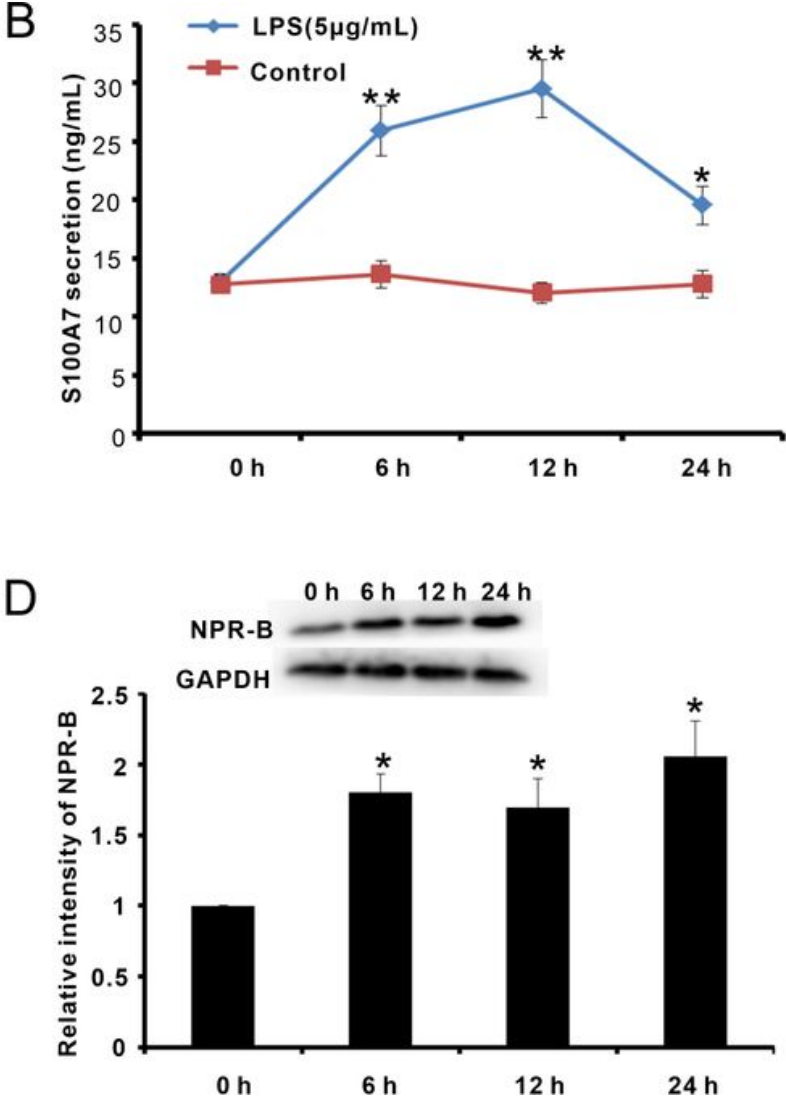

Figure 7

Establishment of goat mastitis model in vitro and the expression of NPR-B and S100A7 in goat mastitis model in vitro. A, Quantitative PCR results showing the mRNAs expression level of IL-6, IL-1 $\beta$ and TNF- $a$ in goat MECs treated by $5 \mu \mathrm{g} / \mathrm{mL}$ LPS for $6 \mathrm{~h}$. B, ELISA results showed the S100A7 concentration in medium in which goat MECs were cultured and treated by $5 \mu \mathrm{g} / \mathrm{mL}$ LPS for $0 \mathrm{~h}, 6 \mathrm{~h}, 12 \mathrm{~h}$ and $24 \mathrm{~h}$ respectively. C, The western-blotting and quantitative analysis results of the S100A7 expression level in goat MECs treated by $5 \mu \mathrm{g} / \mathrm{mL}$ LPS for $0 \mathrm{~h}, 6 \mathrm{~h}, 12 \mathrm{~h}$ and $24 \mathrm{~h}$ respectively. D, The western-blotting and quantitative analysis results of the NPR-B expression level in goat MECs treated by $5 \mu \mathrm{g} / \mathrm{mL}$ LPS for $0 \mathrm{~h}, 6 \mathrm{~h}, 12 \mathrm{~h}$ and $24 \mathrm{~h}$ respectively. *: $p<0.05$ (compared to control); **: $p<0.01$ (compared to control).

\section{Supplementary Files}

This is a list of supplementary files associated with this preprint. Click to download.

- FigureS1.jpg

- FigureS2.jpg

- Figures3.jpg

- SupplementaryMaterialinformation.doc

- TableS1PrimersequencesfortheRTPCRandqPCRanalyses.doc 